\title{
IMPLIKASI KEGIATAN USAHA PENITIPAN DENGAN PENGELOLAAN (TRUST) DALAM AKTIVITAS PERBANKAN TERHADAP PEMBAHARUAN HUKUM PERDATA INDONESIA
}

\section{Tri Handayani}

Dosen Fakultas Hukum Universitas Padjajaran Bandung, Jl. Fakultas Hukum Universitas Padjajaran Jl. Dipati Ukur No. 35 Bandung 40132, Telp. (022) 2503271/6670718, Fax. (022) 6670718, HP. 081313407048 Email: t212h@yahoo.com

\section{Lastuti Abubakar}

Dosen Fakultas Hukum Universitas Padjajaran Bandung, Jl. Fakultas Hukum Universitas Padjajaran Jl. Dipati Ukur No. 35 Bandung 40132, Telp. (022) 2503271/6670718, Fax. (022) 6670718, HP. 08122150155 , Email: lastutiabubakar@yahoo.com

\begin{abstract}
ABSTRAK
Terbitnya Peraturan Bank Indonesia (selanjutnya ditulis PBI) No: 14/7/PBI/2012 Tanggal 23 November 2012 Tentang Kegiatan Trust menambah jenis perjanjian yang berkembang dalam praktik perbankan. Dari sudut pandang hukum, konsep trust masih menimbulkan perdebatan, mengingat secara historis konsep trust berasal dari sistem hukum Anglo-Saxon yang mengenal dual-ownership yang tidak dikenal dalam Hukum Perdata Indonesia. Namun demikian, eksistensi perjanjian trust ini dimungkinkan berdasarkan asas kebebasan berkontrak dalam hukum perjanjian. Dalam tataran praktis, penggunaan konsep trust ini akan bersinggungan dengan kepentingan pemilik dana dan penerima manfaat. Penelitian ini membahas beberapa aspek hukum seperti bagaimana kedudukan perjanjian trust dalam sistem hukum perjanjian di Indonesia, bagaimana pertanggung jawaban bank selaku trustee bila terjadi permasalahan dalam kegiatan trust dan bagaimana implikasi dari kegiatan trust terhadap pembaharuan hukum perdata di Indonesia. Penelitian ini menggunakan metode pendekatan yuridis normatif. Kesimpulan dari penelitian ini adalah kegiatan trust merupakan perjanjian yang didasarkan pada system terbuka dan prinsip kebebasan dalam kontrak. Berdasarkan perjanjian, bank sebagai trustee harus bertanggung jawab terhadap kerugian yang timbul apabila memang diakibatkan oleh kesalahan bank dan perbuatan melawan hukum; mengingat konsep trust mengenal dual ownership yang tidak dikenal dalam sistem hukum benda Indonesia, maka diperlukan pembaruan hukum perdata untuk mengakomodasikan dual ownership.
\end{abstract}

Kata kunci: Trust, dual ownership, hukum perdata. 


\begin{abstract}
ABSTRCT
The issuance of Bank Indonesia Regulation No. 14/7/PBI/2012 regarding Trust add more types of agreements in banking practice. From the legal view, the concept of trust is still debatable, given the concept of trust derived from the Anglo-Saxon legal system that recognize dual -ownership. This concept is not recognize in the legal system agreements in Indonesia, but the existence of the trust agreement is possible based on the principle of freedom of contract in contract law. In practical terms, the use of the concept of trust will intersect with the interests of a third party. Some legal issues have been research in this study are how the Trust agreement under the Indonesia Law of contract; how Bank responsibility as Trustee's for any losses, and how the implications of the Trust against renewal Civil Law. This study utilizes a descriptive analysis, using normative juridical approach. We have conclusion such as: Trust is an agreement that was developed in banking practice based on open systems and the principle of freedom of contract which adopted from Law of contract Based on the agreement, Banks as a trustee shall be liable for losses that incurred caused by Bank negligence in carrying out its functions. Given the concept of custody had unrecognized dual ownership in the Indonesian legal system; hence it is necessary to reform the civil law to accommodate trust activity.
\end{abstract}

Keywords: Trust, dual-ownership, civil law. 


\section{PENDAHULUAN}

Terbitnya Peraturan Bank Indonesia (PBI) No : 14/17/PBI/2012 Tanggal 23 November 2012 Tentang Kegiatan Usaha Bank Berupa Penitipan dengan Pengelolaan (Trust) dalam praktik perbankan telah mengubah peta hukum perjanjian Indonesia. Penggunaan perjanjian trust dalam kegiatan perbankan ini menambah jenis perjanjian tidak bernama (onbenoemde overeemkomsten) yang digunakan dalam aktivitas ekonomi, khususnya oleh institusi keuangan. Sebelumnya, Bank tidak diperkenankan untuk menyelenggarakan kegiatan trust. PBI Trust ini lahir sebagai tindak lanjut dari kebijakan BP Migas tentang penerimaan Devisa Hasil Ekspor (DHE) dan Devisa Utang Luar Negeri (DULN) melalui perbankan di dalam negeri (Surat Kebijakan BP Migas No.kep-0066/BP00000/2008/SO Tahun 2008 mengatur tentang pelaksanaan pengadaan barang dan jasa dengan mengutamakan penggunaan rekening di bank umum nasional). Kebijakan ini dilatarbelakangi oleh fakta bahwa terdapat potensi pasokan devisa yang belum dapat dioptimalkan, khususnya dari sektor Migas. Dana cash call (dana operasional) dari Kontraktor Kontrak Kerjasama (K3S) Migas dan dana yang berasal dari hasil penjualan (revenue) Migas selama ini di kelola oleh Trustee di luar negeri. Hal ini berarti ada sejumlah dana yang terus menerus meningkat sejalan dengan kapasitas produksi migas yang mengendap pada 
trustee dan dapat diinvestasikan kembali dengan seijin BP Migas. Berdasarkan fakta tersebut, dapat dibayangkan andaikata dana tersebut dapat disimpan pada Bank dan ditempatkan pada Investasi di Indonesia melalui kegiatan penitipan dengan pengelolaan. Kebijakan BP Migas yang mewajibkan penempatan dana yang berasal dari kontrak Migas pada bank atau trust fund di dalam negeri dapat menjadi peluang bagi perbankan di Indonesia untuk terlibat dalam industri migas, mendorong peningkatan level of playing field,fee based income dan daya saing terhadap Kantor Cabang Bank Asing (KCBA) di Indonesia (Bank Indonesia, Tanpa Tahun). Berkaitan dengan itu, diperlukan infrastruktur legal yang dapat dijadikan sebagai landasan hukum bagi perbankan untuk memanfaatkan peluang ini, khususnya ketentuan yang memungkinkan Bank secara optimal memanfaatkan kedudukannya sebagai Trustee dalam perjanjian dengan pemilik dana. Kesiapan infrastruktur legal bagi pengembangan jasa perbankan sebagai trustee ini menjadi penting mengingat sistrem hukum Indonesia tidak mengenal pranata hukum trust sebagaimana dikenal dalam sistem hukum common law. Diharapkan dengan dukungan regulasi yang kokoh, potensi pasokan devisa yang semula dikelola oleh trustee di luar negeri dapat dilakukan di dalam negeri dengan mengembangkan jasa perbankan domestik. Hal tersebut juga menjadi dasar pemikiran tersebut Bank Indonesia dalam menerbitkan PBI Trust tentang kgiatan penitipan dengan pengelolaan (trust). 
Landasan hukum yang digunakan dalam penerbitan PBI Trust ini merujuk pada Pasal 6 Huruf i jo Pasal 9 UU No : 10 tahun 1998 Tentang Perubahan UU No: 7 Tahun 1992 tentang Perbankan (UU Perbankan). Pasal 6 Huruf i mengatur bahwa "Bank dapat melakukan kegiatan penitipan untuk kepentingan pihak lain berdasarkan suatu kontrak “. Selanjutnya, Pasal 9 mengatur bahwa "Bank bertanggung jawab untuk menyimpan harta milik penitip, dan memenuhi kewijiban sesuai kontrak ". Selain itu Pasal ini juga menegaskan bahwa harta yang dititipkan harus dicatat secara terpisah dan dalam hal Bank dinyatakan pailit, maka harta yang dititpkan tidak masuk dalam boedel pailit dan harus dikembalikan kepada penitip.

Dalam praktik perbankan, ketentuan Pasal 6 Huruf i jo Pasal 9 UU Perbankan ini menjadi dasar bagi Bank untuk mengembangkan jasanya sebagai Bank Kustodian dan Wali Amanat, yakni lembaga penunjang dalam aktivitas pasar modal.

Bank sebagai Kustodian menyediakan jasa untuk menyelenggarakan kegiatan penitipan dan bertanggung jawab menyimpan efek milik pemegang rekening serta memenuhi kewajiban lain sesuai dengan kontrak antara Kustodian dan pemegang rekening (Pasal 44 ayat 1 UU No. 8 Tahun 1995). Demikian juga Bank sebagai wali amanat akan bertindak untuk mewakili kepentingan pemegang efek bersifat utang baik di dalam maupun di Iuar pengadilan (Pasal 51 ayat 2 UU No. 8 Tahun 1995). Ke dua jasa Bank 
tersebut menempatkan Bank sebagai pihak yang akan melakukan kewajiban untuk kepentingan pihak lain sesuai dengan perjanjian. Perjanjian Penitipan dengan Pengelolaan (trust) sebagaimana diatur dalam PBI Trust merupakan pengembangan jenis perjanjian selain ke dua jasa tersebut. Dalam kegiatan penitipan dengan pengelolaan (trust), selain menerima penitipan aset, dalam hal ini berupa aset finansial, Bank juga diperkenankan mengelola aset finansial yang dititipkan berdasarkan persetujuan pemilik dana.

Secara teoritis terdapat perbedaan yang substansial antara perjanjian Penitipan dengan Pengelolaan (trust) yang di atur dalam PBI Trust dengan konsep trust, yang berasal dari common law system. Dalam implementasinya di Indonesia, konsep trust dihadapkan pada aspek legal, mengingat konsep trust dalam sistem hukum Anglo-Saxon (common law system) mengenal dual-ownership, yang menempatkan trustee selaku pemilik secara hukum (legal owner) terhadap harta trust untuk kepentingan pihak ketiga (beneficiary) sebagai pemilik manfaat (beneficiary owner). Konsep dual ownership ini tidak dikenal dalam sistem hukum perdata Indonesia. Hal ini menyebabkan implementasi konsep trust di Indonesia harus diadaptasikan dengan sistem hukum Indonesia. Namun demikian, eksistensi perjanjian trust itu sendiri, dimungkinkan berdasarkan sistem terbuka dan asas kebebasan berkontrak dalam hukum perjanjian (Pasal 1319 jo Pasal 1338 Ayat 1). Dalam perkembangannya, konsepsi trust banyak digunakan dalam aktivitas 
bisnis, khususnya digunakan oleh perusahaan -perusahaan yang menawarkan jasa untuk mengelola investasi bagi para pemilik modal, yang dikenal dengan trust company (Mack. William \& Donald J. Keser, 1938 : 343).

Dalam tataran praktis, penggunaan konsep trust ini akan bersinggungan dengan kepentingan pihak ketiga, yakni pemilik dana yang dititipkan dan dikelola oleh pihak bank. Berdasarkan PBI, bank dimungkinkan bertindak sebagai agen investasi dimana Bank akan bertindak sebagai trustee yang melakukan investasi aset berdasarkan instruksi yang jelas dan rinci dari settlor, yang disesuaikan dengan jenis kegiatan atau instrumen yang digunakan. Berdasarkan PBI tersebut, hubungan hukum yang mendasari kegiatan usaha penitipan dan pengelolaan ini didasarkan pada perjanjian, yakni perjanjian trust.

Sebagaimana telah dijelaskan , pranata trust berasal dari common law system. Oleh karena itu perlu dikaji bagaimana penerapan perjanjian penitipan dan pengelolaan ( trust) berdasarkan PBI ini dalam praktik perbankan, agar dapat mengakomodasikan maksud dan tujuan berlakunya PBI Trust tersebut. Selain itu, perlu dikaji kedudukan perjanjian trust ini dalam sistem hukum perdata Indonesia, khususnya hukum perjanjian dan hukum benda. Berdasarkan latar belakang permasalahan sebagaimana diuraikan di atas, maka dapat diidentifikasi beberapa permasalahan, antara lain : 
1. Bagaimana kedudukan perjanjian penitipan dan pengelolaan (trust) dalam sistem hukum perjanjian Indonesia?

2. Bagaimana tanggung jawab Bank terhadap pengelolaan aset finansial yang dititipkan dan dikelola oleh Bank?

3. Apakah implikasi hukum dari kegiatan penitipan dan pengelolaan (trust) terhadap pembaharuan hukum Perdata Indonesia?

\section{METODE PENELITIAN}

\section{A. Spesifikasi Penelitian}

Penelitian ini bersifat deskriptif analitis, yaitu membuat pencandraan secara sistematis, faktual dan akurat mengenai faktafakta (Sumadi, 1988, : 19). Juga dimaksudkan untuk memberikan data seteliti mungkin tentang manusia dan gejala lainnya (Soerjono, Soekanto, 1982 : 10). Dengan demikian penelitian ini akan mencoba mengkaji dan memaparkan berbagai permasalahan aspek hukum dan fakta serta gejala lainnya yang berkaitan dengan perkembangan jasa perbankan dengan terbitnya PBI No : 14/2012 Tentang Kegiatan Usaha Penitipan dengan Pengelolaan (Trust) kemudian menganalisisnya guna memperoleh gambaran yang utuh dan menyeluruh tentang permasalahan hukum yang berkiatan dengan 
implemaentasi Kegiatan Penitipan dengan Pengelolaan pada perbankan.

B. Metode Pendekatan

Metode pendekatan yang digunakan adalah metode pendekatan yuridis normatif, yaitu menelusuri, mengkaji dan meneliti data sekunder yang berkaitan dengan materi peneltian ini. Digunakannya pendekatan yuridis dengan pertimbangan masalah yang diteliti berkisar pada keterkaitan suatu peraturan dengan peraturan lainnya.

C. Tahap Penelitian dan Teknik Pengumpulan Data

Penelitian ini dilakukan dalam dua tahap, yaitu penelitian kepustakaan (library research) dan penelitian lapangan (field research). Penelitian kepustakaan bertujuan untuk mengkaji, meneliti dan menelusuri data sekunder yang berupa bahan hukum primer yang berkaitan dengan penelitian ini antara lain :

a. Kitab Undang-Undang Hukum Perdata.

b. Undang-Undang No. 7 Tahun 1992 sebagaimana diubah dengan UU No. 10 Tahun 1998 Tentang Perbankan.

c. Undang-Undang No. 23 Tahun 1999 sebagimana diubah dengan UU No : 3 Tahun 2004 Tentang Bank Indonesia. 
d. Peraturan Bank Indonesia No 14/17/PBI/2012 tentang Kegiatan usaha Bank Penitipan dan Pengelolaan (trust)

Studi kepustakaan juga meliputi bahan-bahan hukum sekunder berupa literatur, hasil penelitian, lokakarya yang berkaitan dengan materi penelitian. Untuk melengkapi dapat digunakan bahan hukum tersier berupa kamus atau artikel pada majalah, surat kabar. Selain studi kepustakaan pengumpulan data juga dilakukan melalui penelitian lapangan, tujuannya mencari data - data lapangan (data primer) yang berkaitan dengan materi penelitian dan berfungsi sebagai pendukung data sekunder.

D. Teknik Pengumpulan Data

Teknik pengumpulan data yang akan digunakan dalam penelitian ini adalah studi dokumen untuk mengumpulkan data sekunder, sedangkan untuk mengumpulkan data primer dilakukan dengan wawancara dengan responden yang terpilih.

E. Lokasi Penelitian

Penelitian ini dilakukan di Jakarta dan Bandung.

F. Metode Analisis Data

Data yang telah dikumpulan baik itu data sekunder maupun data primer, keseluruhannya dianalisis berdasarkan analisis kualitatif 
dan hasilnya akan dipaparkan secara deskriptif, sehingga diperoleh gambaran yang menyeluruh tentang permasalahan-permasalahan yang diteliti.

\section{HASIL PENELITIAN DAN ANALISIS}

Perbankan Indonesia mempunyai fungsi penting dalam aktivitas bisnis dan pembangunan ekonomi, khususnya sebagai intermediary yang mempertemukan pihak yang memiliki kelebihan dana (surplus of fund)

dengan pihak yang memerlukan dana (lack of fund). Melalui fungsi itu, perbankan menjadi urat nadi perekonomian Indonesia, yang menggerakkan perekonomian dengan visi untuk mendorong pertumbuhan ekonomi (visi Arsitektur Perbankan Indonesia PI dalam Arsitektur Perbankan Indonesia/ API). Oleh karena itu, perbankan terus menerus mengembangkan jasanya untuk dapat memanfaatkan peluang global, termasuk memfasilitasi kegiatan penitipan dengan pengelolaan (trust) sebagai salah satu cara mengoptimalkan dana-dana yang berasal dari devisa hasil ekspor yang selama ini disimpan pada bank di luar negeri. Di sisi lain, diperlukan kesiapan dan penguatan regulasi yang dapat dijadikan dasar bagi pengembangan jasa bank sebagai trustee. Sebelum Bank Indonesia menerbitkan PBI Trust, konsep trust memang 
sudah banyak digunakan dalam aktivitas bisnis, khususnya dalam aktivitas keuangan. Pasar Modal Indonesia terlebih dahulu mengadaptasi dan mengadopsi konsep trust untuk mengisi kekosongan hukum dalam sistem hukum perdata Indonesia, khususnya terkait dengan dual ownership. Kontrak Investasi Kolektif (KIK), dana investasi yang dikelola oleh manajer investasi, fungsi Lembaga Kliring dan Penjaminan serta Lembaga Penyelesaian dan Penyimpanan di Pasar Modal Indonesia mengadaptasi trust dalam sebagian hubungan hukumnya dengan pihak ketiga, khususnya para investor.

Di sisi lain, khusunya bagi perbankan Indonesia, kehadiran PBI Trust membuka peluang bagi Bank untuk bertindak sebagai Trustee, dan diharapkan pula mampu memanfaatkan peluang untuk mendapatkan penghasilan melalui fee based income serta meningkatkan daya saing terhadap Kantor Cabang Bank Asing (KCBA) di Indonesia.

A. Kesiapan perbankan Indonesia untuk mengembangkan jasa Penitipan dengan Pengelolaan

Eksistensi Kegiatan Usaha Penitipan dengan Pengelolaan (Trust) merujuk pada UU Perbankan, khususnya dalam Pasal 6 (i) jo Pasal 9 UU Perbankan, yang menjadi landasan bagi bank untuk melayani jasa penitipan berdasarkan kontrak. Dalam praktik perbankan saat ini, Pasal 6 (i) jo Pasal 9 ini digunakan Bank untuk 
melayani dan menyediakan jasa sebagai Kustodian dan Wali Amanat, yakni lembaga penunjang dipasar modal. Oleh karena itu, Bank yang menjadi Bank Kustodian dan Wali Amanat selain tunduk pada UU Perbankan, harus tunduk pula pada regulasi di Pasar Modal, khususnya UU No : 8 Tahun 1995 Tentang Pasar Modal.

Kegiatan Penitipan dengan Pengelolaan (Trust) ini berbeda dengan ke dua jasa tersebut, karena dalam kegiatan ini Bank diberi kewenangan yang lebih luas dari penitipan, yakni kewenangan mengelola aset finansial yang dititipkan oleh pemilik dana sesuai dengan ketentuan khusus yang berlaku, yakni PBI Trust.

Berdasarkan hasil penelitian, saat ini baru terdapat 3 Bank umum nasional yang memperoleh persetujuan Bank Indonesia untuk memberikan jasa penitipan dengan pengelolaan (trust) di Indonesia, yaitu Bank Mandiri, Tbk, Bank BNI, Tbk, dan Bank BRI (Hasil wawancara pada Selasa tanggal 26 November 2013 pkl 15.00 selesai). Pemilihan ke 3 bank umum nasional ini berdasarkan pertimbangan bahwa selain telah memenuhi ketentuan yang berlaku, juga memilik kesiapan teknologi informasi dan pertimbangan dari Bank Indonesia selaku regulator. Pemilihan ke 3 bank tersebut tentunya harus terlebih dahulu memenuhi persyaratan yang ditentukan dalam peraturan perundang-undangan, khususnya PBI 
Trust. Bank yang akan melakukan kegiatan penitipan dengan pengelolaan (trust) terlebih dahulu wajib memenuhi persyaratan sebagaimana dicantumkan dalam Pasal 15 PBI Trust yaitu :

1. Harus berbadan hukum Indonesia;

2. merupakan bank devisa dengan modal inti paling sedikit sebesar Rp.5 triliun;

3. rasio Kewajiban Penyediaan Modal Minimum paling rendah 13 \% selama 18 bulan terakhir berturut-turut;

4. memiliki tingkat kesehatan Bank paling rendah Peringkat Komposit 2 pada periode penilaian dalam 12 bulan terakhir secara berturut-turut, dan paling rendah Peringkat Komposit 3 pada periode penilaian dalam 6 bulan sebelum periode;

5. mencantumkan rencana kegiatan trust dalam rencana bisnis Bank dan

6. memiliki kapasitas untuk melakukan kegiatan trust berdasarkan hasil penilaian Bank Indonesia.

Selanjutnya, dalam melakukan kegiatan trust, Bank wajib memenuhi prinsip sebagaimana diatur dalam Pasal 4 PBI Tentang kegiatan Usaha Bank Berupa Penitipan dengan Pengelolaan (trust) yaitu sebagai berikut : 
a. Kegiatan Trust dilakukan oleh unit kerja yang terpisah dari unit kegiatan Bank lainnya;

b. harta yang dititipkan Settlor untuk dikelola oleh Trustee terbatas pada aset finansial;

c. harta yang dititipkan Settlor untuk dikelola oleh Trustee dicatat dan dilaporkan terpisah dari harta Bank;

d. dalam hal Bank yang melakukan kegiatan Trust di likuidasi, semua harta Trust tidak dimasukkan dalam harta pailit (boedel pailit) dan dikembalikan kepada Settlor atau dialihkan kepada

Trustee pengganti yang dialihkan kepada Trustee pengganti yang ditunjuk Settlor;

e. kegiatan Trust dituangkan dalam perjanjian tertulis antara Trustee dan Settlor;

f. trustee menjaga kerahasiaan data dan keterangan terkait kegiatan Trust sebagaimana diatur dalam perjanjian trust, kecuali untuk pelaporan kepada Bank Indonesia;

g. Bank yang melakukan kegiatan Trust tunduk pada ketentuan dan peraturan perundang-undangan yang berlaku.

Mengacu pada prinsip-prinsip di atas, dapat disimpulkan bahwa kegiatan trust oleh perbankan ini berlandaskan pada 
kesepakatan para pihak yang akan dituangkan dalam perjanjian trust. Para pihak dalam perjanjian ini adalah bank selaku trustee ; Settlor selaku pemilik aset yang akan dititipkan dan dikelola oleh Trustee, serta beneficiary, yaitu pihak yang menerima manfaat dari kegiatan trust. Perjanjian inilah yang akan menjadi dasar pelaksanaan hak dan kewajiban para pihak, khususnya Bank sebagai trustee. Mengingat dasar hubungan hukum para pihak dalam kegiatan trust ini adalah perjanjian, maka tentu berlaku pula Buku III KUHPerdata Tentang Perikatan sebagai lex generalis, termasuk asas-asas yang berlaku dalam hukum perjanjian.

Berbeda dengan fungsi Trustee dalam sistem common law, di Indonesia, Bank selaku Trustee mempunyai fungsi yang terbatas dalam mengelola aset finansial yang dititipkan, yakni berfungsi sebagai :

a. agen Pembayar (paying agent); berupa kegiatan menerima dan melakukan pemindahan uang dan/atau dana, serta mencatat arus kas masuk dan keluar untuk dan atas nama Settlor.

b. Agen investasi dana baik secara konvensional maupun berdasarkan prinsip syariah; berupa kegiatan menempatkan, mengkonversi, melakukan lindung nilai (hedging) dan 
mengadministrasikan penempatan dana untuk dan atas nama Settlor.

c. Agen peminjaman (borrowing agent) dan/atau agen pembiayaan berdasarkan prinsip syariah, untuk dan atas nama Settlor sesuai perjanjian Trust.

Seluruh kegiatan di atas wajib dilakukan berdasarkan instruksi tertulis dari Settlor sebagaimana dimuat dalam perjanjian Trust. Dapat dikatakan bahwa kewenangan Bank sebagai Trustee dalam PBI Trust tidak sebesar Trustee dalam sistem common law, yang memberikan kepercayaan penuh pada Trustee untuk mengelola harta trust sepanjang patuh terhadap prinsip-prinsip (maxim) trust.

Pasal 9 PBI Trust secara eksplisit melarang Trustee melakukan kegiatan di luar yang diatur dalam perjanjian Trust, baik atas inisiatif sendiri maupun berdasarkan perintah tertulis dari Settlor. Mengacu pada Pasal 9 ini, maka kedudukan Bank sebagai Trustee dalam PBI lebih mendekati kedudukan sebagai agen atau penerima kuasa untuk mengelola aset finasial milik Settlor, atau perjanjian guna kepentingan pihak ketiga seperti diatur dalam Pasal 1317 KUHPerdata. Disini tampak bahwa PBI berhati-hati mengadaptasi konsep Trust. Kehati-hatian ini menurut analisa peneliti diperlukan mengingat Indonesia belum memiliki ketentuan khusus tentang Trust 
yang dapat menjadi ketentuan payung, dan dapat memberikan perlindungan hukum maksimal bagi para pihak, khususnya bagi pemilik dana. Selain itu, kegiatan penitipan dengan pengelolaan (trust) ini juga harus memperhatikan prinsip kehati-hatian Bank / prudential banking principle (Pasal 2, 8 dan 29 UU Perbankan).

Bank yang melakukan kegiatan trust juga wajib tunduk pada ketentuan dan peraturan perundang-undangan yang mengatur mengenai penerapan anti pencucian uang dan pendanaan terorisme. Berkenaan dengan kewajiban tersebut, Bank harus melakukan customer due dilligence; enhanced due dilligence, dan pelaporan transaksi keuangan mencurigakan, untuk memastikan harta trust tidak berasal dari kejahatan dan/atau tidak bertujuan untuk pencucian uang dan pendanaan terorisme.

Berdasarkan PBI Trust dan perjanjian trust sebagai landasan hukum bagi kegiatan penitipan dengan pengelolaan (Trust), Bank yang akan melakukan kegiatan trust perlu mempersiapkan berbagai aspek antara lain kesiapan untuk menerapkan manajemen risiko; transparansi informasi dan kewajiban pelaporan. Seluruh aktivitas Bank sebagai Trustee sebelum dan sesudahnya berada di bawah pengawasan dan pemantauan regulator. Saat PBI ini berlaku persetujuan dan penegasan bagi 3 Bank yang akan melaksanakan 
kegiatan Trust serta pemantaun masih dilakukan oleh Bank Indonesia.

Berkenaan dengan fungsi pengawasan terhadap aktivitas trust, Bank Indonesia berperan sebelum dan sesudah Bank melakukan kegiatan Trust. Penunjukan Bank selaku Trustee terlebih dahulu wajib memperoleh persetujuan prinsip dan surat penegasan dari Bank Indonesia. Persetujuan prinsip bertujuan untuk menilai kesiapan Bank dalam melakukan kegiatan Trust.

Selanjutnya, sebagai tindak lanjut dari PBI Trust, Bank Indonesia mengeluarkan Surat Edaran No : 15/10/DPNP/2013 Tentang Laporan Kegiatan Penitipan dengan Pengelolaan (Trust) Bank Umum yang disampaikan Bank Umum. Berdasarkan kewajiban pelaporan tersebut, Bank Indonesia melakukan pemantauan patuh tidaknya Bank selaku Trustee terhadap kewajiban baik berdasarkan PBI dan ketentuan lainnya maupun perjanjian trust.

Dalam menjalankan kegiatan trust Bank wajib menerapkan manajemen risiko dengan berpedoman pada ketentuan Bank Indonesia yang mengatur penerapan manajemen risiko bagi bank umum, yang sekurang-kurangnya mencakup (Peraturan Bank Indonesia No 14/17/PBI/2012 Bab VII ): 
1. Pengawasan aktif Dewan Komisaris dan Direksi serta Dewan Pengawas Syariah;

2. Kecukupan kebijakan dan prosedur;

3. Kecukupan proses identifikasi, pengukuran, pemantauan, dan pengendalian risiko serta sistem informasi manajemen,

4. Pengandalian intern.

Selain dari aspek internal perbankan, maka kesiapan dan keberagaman instrumen investasi di dalam negeri juga tak kalah penting bagi pengembangan kegiatan penitipan dengan pengelolaan (trust). Ketersediaan beragam instrumen investasi di Indonesia juga akan menjadi daya tarik bagi settlor untuk menitipkan aset finansialnya pada trustee. PBI Trust mengatur investasi mana saja yang dapat dilakukan oleh Bank selaku Trustee. Dalam hal settlor menghendaki investasi di luar ketentuan PBI, maka Bank wajib menunjuk manajer investasi. Jenis investasi yang harus melalui manajer investasi merupakan instrumen investasi di pasar modal antara lain saham, obligasi atau sukuk korporasi, reksadana atau reksadana syariah, efek beragun aset dan Medium Term Notes (MTN).

B. Perjanjian Penitipan dengan Pengelolaan(Trust) sebagai Perjanjian Tidak Bernama yang berkembang dalam Praktik Perbankan. 
Sebagaimana telah diuraikan sebelumnya, kegiatan penitipan dengan pengelolaan (trust) ini wajib dituangkan dalam perjanjian tertulis. Sistem terbuka dan asas kebebasan berkontrak yang terkandung dalam hukum perjanjian membuat perjanjian trust dapat diterima sebagai salah jenis perjanjian di luar KUHPerdata. Tidak terdapat permasalahan hukum terkait keberadaan perjanjian trust dalam praktik perbankan di Indonesia. Namun demikian, diperlukan kehati-hatian dalam menerjemahkan perjanjian trust ini, khususnya terkait kewenangan Bank selaku Trustee. Kedudukan Bank selaku legal owner tentunya membawa implikasi yuridis terhadap kewenangan bertindak terhadap aset milik settlor yang dititipkan dan dikelola oleh Bank untuk kepentingan beneficiary. Dalam perkembangan praktik bisnis finansial, settlor dapat juga bertindak sebagai penerima manfaat (beneficiary). Berlakunya dual ownership inilah yang harus diatur dan diterjemahkan dengan baik dalam regulasi dan perjanjian, mengingat KUHPerdata khususnya hukum benda tidak mengenal dual paownership. Oleh karena itu, sangat penting keberadaan PBI Trust sebagai ketentuan yang memberikan rambu-rambu bagi perjanjian trust. Dapat dikatakan bahwa PBI Trust inilah yang akan membatasi para pihak dalam menuangkan klausul-klausul dalam 
perjanjian. Sebagaimana jenis perjanjian tidak bernama lainnya, maka hal terpenting bagi perjanjian trust ini adalah terpenuhinya syarat sah suatu perjanjian yang diatur dalam Pasal 1320 KUHPerdata. Tidak ada keraguan bahwa perjanjian trust ini telah memenuhi persyaratan sahnya perjanjian, yakni :

a. adanya kesepakatan antara settlor dan trustee untuk membuat perjanjian penitipan dengan pengelolaan yang dituangkan dalam bentuk tertulis dan ditandatangani oleh ke dua belah pihak (syarat kesepakatan para pihak) baik Bank sebagai trustee dan settlor

b. Bank sebagai trustee dan pemilik dana (settlor) adalah badan hukum yang merupakan subjek hukum yang cakap melakukan perbuatan hukum, termasuk membuat perjanjian. Bank yang bertindak sebagai trustee harus memenuhi persyaratan khusus yang diatur dalam PBI dan ketentuan terkait lainnya, sedangkan settlor adalah pemilik dana berupa nasabah korporasi (syarat cakap untuk melakukan perjanjian)

c. objek atau hal tertentu dalam Perjanjian Penitipan dengan Pengelolaan adalah jasa penitipan dengan pengelolaan aset finansial yang akan dititipkan dan dikelola oleh trustee untuk kepentingan beneficiary (syarat hal tertentu) 
d. perjanjian Penitipan dengan pengelolaan (trust) diatur dalam peraturan Bank Indonesia, dan tunduk pada peraturan lainnya yang bersifat memaksa, khususnya UU Perbankan.

Oleh karena itu, keberadaan perjanjian Pengelolaan dengan penitipan (trust) di Indonesia, khususnya di perbankan dapat diterima sebagai jenis perjanjian baru yang dapat digunakan sebagai upaya untuk meningkatkan peran perbankan dalam mendorong perekonomian Indonesia, khususnya untuk meningkatkan pengelolaan cadangan devisa negara. Namun demikian, tentu saja perjanjian Penitipan dengan pengelolaan ini harus disesuaikan dengan sistem hukum Indonesia, mengingat sistem hukum Indonesia tidak mengenal konsep trust sebagaimana dikenal dalam sistem common law. Oleh karena itu, diperlukan penyesuaian atau harmonisasi agar dapat digunakan secara baik.

C. Perbedaan Perjanjian Penitipan dengan Pengelolaan (trust) menurut PBI Trust dengan konsep Trust dalam common law system

Perjanjian Penitipan dengan Pengelolaan (trust) yang berkembang dalam praktik perbankan pada prinsipnya mengadopsi sebagian kecil dari konsep trust yang dianut oleh sistem common law, yang berlaku di negara-negara Anglo - Saxon. Sistem hukum di 
negara Anglo Saxon mengakui trust sebagai pranata yang unik. Trust tidak berdiri sendiri, melainkan merupakan bagian dari suatu sistem yang lebih besar, yaitu equity (Peter. Joseph Loghlin : 3). Trust merupakan satu kontribusi terbesar dari equity(Angela Sydenham, 2000 : 1). Dalam implementasinya berlaku prinsip equity follows the law, dimana equity ini menjadi pelengkap dari hukum yang dianggap belum mampu memberikan rasa keadilan sehingga equity berfungsi untuk mengisi kekosongan hukum. Apa yang sudah diputuskan berdasarkan equity tidak dapat dibatalkan oleh hukum (Gilissen. John \& Frits Gorle, 2005: 347). Terdapat perbedaan yang mendasar antara trust sebagai perjanjian tidak bernama dalam sistem hukum perjanjian Indonesia dengan konsep trust dalam sistem common law. Beberapa perbedaan substansial tersebut dapat diidentifikasikan sebagai berikut :

Tabel III.1.

Perbedaan Antara Perjanjian Trust dIm PBI dengan Trust dalam common law system

\begin{tabular}{|l|l|l|l|}
\hline Perbedaan & $\begin{array}{l}\text { Perjanjian dalam } \\
\text { Penitipan dengan } \\
\text { Pengelolaan }\end{array}$ & $\begin{array}{l}\text { Trust } \\
\text { sistem common } \\
\text { law }\end{array}$ & \\
\hline Sumber Hukum & Ketentuan & $\begin{array}{l}\text { Equity } \\
\text { (kepatutan) yang } \\
\text { perundang- } \\
\text { undangan dan } \\
\text { Perjanjian }\end{array}$ & $\begin{array}{l}\text { Dalam dan } \\
\text { timulam Indonesia, } \\
\text { berkembang di di }\end{array}$ \\
kepatutan \\
merupakan salah \\
\hline
\end{tabular}




\begin{tabular}{|c|c|c|c|}
\hline & $\begin{array}{l}\text { Penitipan dengan } \\
\text { pengelolaan } \\
\text { (trust) }\end{array}$ & Iuar hukum & $\begin{array}{l}\text { satu asas yang } \\
\text { terkandung } \\
\text { dalam perjanjian }\end{array}$ \\
\hline $\begin{array}{l}\text { Kedudukan } \\
\text { trustee }\end{array}$ & $\begin{array}{l}\text { Pihak yang } \\
\text { melakukan } \\
\text { kegiatan } \\
\text { penitipan dengan } \\
\text { pengelolaan } \\
\text { berdasarkan } \\
\text { perintah settlor }\end{array}$ & $\begin{array}{l}\text { Pihak yang } \\
\text { mengelola aset } \\
\text { trust berdasarkan } \\
\text { maxim/prinsip } \\
\text { trust. }\end{array}$ & $\begin{array}{l}\text { Trustee dalam } \\
\text { perjanjian } \\
\text { penitipan dengan } \\
\text { pengelolaan } \\
\text { mempunyai } \\
\text { kewenangan } \\
\text { terbatas, yakni } \\
\text { berdasarkan } \\
\text { perintah settlor. }\end{array}$ \\
\hline Aset/dana trust & $\begin{array}{ll}\text { Bukan } & \text { milik } \\
\text { trustee }\end{array}$ & $\begin{array}{l}\text { Secara legal } \\
\text { diakui sebagai } \\
\text { milik trustee }\end{array}$ & \begin{tabular}{l}
\multicolumn{2}{c}{ bankcruptcy } \\
remote diatur \\
dalam PBI, tidak \\
berlaku demi \\
hukum
\end{tabular} \\
\hline $\begin{array}{l}\text { Kepemilikan thd } \\
\text { aset trust }\end{array}$ & $\begin{array}{l}\text { Tidak dikenal } \\
\text { dual ownership }\end{array}$ & $\begin{array}{ll}\text { Dikenal } & \text { dual } \\
\text { ownership } & \end{array}$ & $\begin{array}{l}\text { Sistem hukum } \\
\text { benda tidak } \\
\text { mengenal } \\
\text { pemisahan antara } \\
\text { pemilik secara } \\
\text { hukum dan } \\
\text { pemilik manfaat, } \\
\text { namun mengenal } \\
\text { kepemilikan } \\
\text { bersama (mede } \\
\text { eigendom) }\end{array}$ \\
\hline
\end{tabular}

Sumber : diolah oleh Tim Peneliti

Berdasarkan perbedaan di atas, maka dapat dilihat bahwa perjanjian penitipan dengan pengelolaan (trust) dalam praktik perbankan tidak sepenuhnya sama dengan konsep trust. Namun demikian, PBI Trust telah cukup memberikan dasar bagi kepastian dan perlindungan hukum bagi pemilik aset yang akan dikelola oleh bank selaku trustee. Hal ini dapat dilihat dari implementasi 
bankcrupty remote sebagaimana diatur dalam Pasal $4 d$ PBI Trust. Berdasarkan Pasal tersebut, walaupun Bank dianggap sebagai pemilik secara hukum (legal owner), maka apabila Bank tersebut dilikuidasi atau dinyatakan pailit, maka harta trust tidak dapat dimasukkan dalam harta pailit (boedel pailit), dan dikembalikan kepada settlor atau dialihkan kepada trustee pengganti yang ditunjuk settlor.

Berdasarkan analisa, maka dapat dikatakan bahwa praktik perjanjian trust oleh perbankan Indonesia semata-mata ditujukan untuk mengotimalkan dan mengembangkan jasa perbankan dalam menunjang perekonomian Indonesia melalui pengelolaan devisa hasil ekspor dan dana yang selama ini dikelola oleh trustee di luar negeri. Oleh karena itu, kehadiran perjanjian trust ini sepatutnya disambut baik, dengan tetap mengkaji kesiapan aspek hukum terkait guna mendukung kegiatan ini. Beberapa aspek hukum yang diperlukan untuk mendukung kegiatan trust di Indonesia antara lain adanya landasan hukum bagi keberadaan dual ownership dalam sistem hukum

benda Indonesia sebagai dasar bagi Bank agar dapat mengelola aset se optimal mungkin berdasarkan kepercayaan pemilik aset.

Berbeda dengan sistem common law, dimana trust muncul untuk mengisi kekosongan hukum guna memenuhi rasa keadilan 
berdasarkan kepatutan (equity), maka perjanjian trust harus memperhatikan asas kepatutan sebagai salah satu asas dalam hukum perjanjian. Bukan hal yang mudah untuk menerjemahkan bagaimana implementasi asas kepatutan dalam trust, oleh karena itu diperlukan adanya upaya agar asas ini menjelma dalam peraturan dan pedoman yang konkrit untuk memberikan perlindungan dan kepastian hukum bagi para pihak.

D. Tanggung jawab Terbatas Bank sebagai trustee dalam Perjanjian Penitipan dengan Pengelolaan.

Salah satu alasan diterbitkannya PBI tentang trust tidak dapat dilepaskan keinginan untuk dapat menarik dana atau aset finansial yang semula disimpan di bank trust di luar negeri untuk disimpan dan dikelola melalui berbagai instrumen investasi di Indonesia. Pemilik aset sebagai investor tentu berharap agar dana yang diinvestasikan oleh trustee dapat kembali beserta keuntungan (return) yang diperoleh. Oleh karena itu, baik regulasi maupun perjanjian trust harus dapat memberikan kepastian dan perlindungan hukum untuk menjaga kepercayaan pemilik dana (settlor).

Berdasarkan hal itu, maka kesiapan aspek legal yang dapat menjamin kepastian dan perlindungan terhadap aset trust menjadi 
sangat penting untuk mengembangkan kegiatan penitipan dengan pengelolaan. Berbeda dengan konsep trust dalam common law, dimana trustee secara yuridis adalah pemilik harta trust maka PBI trust tidak mengadopsi konsep tersebut. Hal ini dapat disimpulkan dari Pasal 1 PBI Trust bahwa harta yang akan dititipkan dan dikelola oleh trust adalah harta milik settlor. Pasal ini menegaskan bahwa tidak ada dual ownership dalam kegiatan penitipan dengan pengelolaan (trust) berdasarkan PBI Trust.

Eksistensi dual ownership sebagai ciri trust ini justru merupakan salah satu hambatan yuridis dalam penerapan konsep trust di Indonesia. Dalam trust, terdapat dua pemilik atas satu objek (harta trust) yakni trustee sebagai legal owner atau pemilik secara legal atas harta trust yang yang dikelolanya dan beneficiary sebagai pemilik manfaat. Kepemilikan atas satu objek yang terpisah pada subjek hukum yang berbeda, tidak dikenal dalam sistem hukum benda Indonesia. Selain itu, hambatan aspek legal lainnya adalah kedudukan kekayaan trust yang beralih kepada trustee sebagai legal owner. Kedua hal ini menimbulkan kesulitan bagi sistem hukum Indonesia untuk menggunakan konsep trust, khususnya sistem hukum perjanjian untuk menentukan hak dan kewajiban para pihak dalam perjanjian trust di Indonesia. Keleluasan trustee untuk mengelola 
dana trust harus dibatasi baik oleh perjanjian maupun oleh ketentuan perundang-undangan, mengingat trustee dalam perjanjian penitipan dengan pengelolaan (trust) bukan pemilik secara hukum. Namun demikian, untuk mengantisipasi kebutuhan dalam praktik, eksistensi perjanjian trust dapat diakui sebagai salah satu perjanjian yang berkembang dalam praktik perbankan. Konsepsi dual ownership dan peralihan kekayaan trust pada trustee harus dicarikan jalan keluarnya, agar perjanjian trust di Indonesia mempunyai landasan hukum yang kokoh. Untuk menjamin dan memberikan perlindungan hukum bagi pemilik kekayaan/dana yaitu settlor, maka PBI Trust dengan tegas mengatur bahwa dana trust tidak beralih, tidak masuk ke dalam kekayaan Bank atau boedel pailit bank, serta harus dibuat catatan terpisah dengan kekayaan Trust.

Tanggung jawab Bank selaku trustee dalam kegiatan penitipan dengan pengelolaan terbatas pada aset yang dititipkan dan dikelola berdasarkan perintah settlor. Bank tidak bertanggung jawab terhadap kerugian investasi yang timbul karena sifat investasi. Sepanjang tidak bertentangan dengan instruksi settlor yang dituangkan dalam perjanjian trust, maka Bank yang melaksanakan 
kegiatan trust tidak dapat dimintai pertanggungjawaban (Pasal 7 ayat 4 PBI). Dalam hal settlor menginstruksikan agar Trustee melakukan kegiatan investasi dana trust di luar jenis investasi yang telah ditentukan oleh PBI, maka investasi tersebut harus dilakukan oleh Manajer Investasi. Manajer investasi adalah Pihak yang kegiatan usahanya mengelola portofolio efek untuk para nasabah atau mengelola portofolio investasi kolektif untuk sekelompok nasabah, sebagaimana dimaksud dalam UU No : 8 Tahun 1995 tentang Pasar Modal. Dalam hal ini, Bank sebagai trustee akan bertindak sebagai agen pembayar, atau agen yang menghubungkan manajer investasi dengan settlor. Disini fungsi perantara sangat menonjol dibandingkan fungsi trustee. Dalam hal terjadi kerugian terhadap aset finansial yang dititipkan dan dikelola oleh Bank selaku Trustee, maka Trustee tidak bertanggung jawab atas kerugian dari investasi dana sepanjang investasi dana tersebut telah sesuai dengan instruksi Settlor dalam perjanjian Trust. Berdasarkan penafsiran argumentum a contrario, Bank dapat dimintai pertanggungjawaban atas kerugian yang timbul dari kegiatan pengelolaan dengan penitipan (trust) berdasarkan dua hal, yakni : 
1. Wanprestasi atau tidak melakukan kewajiban sesuai perjanjian trust,

2. Perbuatan melawan hukum, apabila Bank selaku trustee tidak mengindahkan kewajiban berdasarkan ketentuan perundangundangan, khususnya PBI Trust.

Pasal 9 PBI Trust antara lain melarang Trustee unutk memanfaatkan harta Trust untuk kepentingan diri sendiri; dan atau melakukan kegiatan di luar yang telah diatur dalam perjanjian trust, baik atas inisiatif sendiri maupun berdasarkan perintah tertulis dari Settlor. Peneliti berkesimpulan bahwa tentu saja Bank sebagai Trustee dapat menambahkan kegiatan dalam rangka mengelola aset finansial milik Settlor sepanjang disepakati oleh ke dua belah pihak dan dituangkan dalam perjanjian tertulis atau dengan melakukan amandemen terhadap perjanjian trust yang sudah ada. Berkenaan dengan kerugian yang muncul sebagai risiko dalam berinvestasi, semisal kerugian yang timbul akibat turunnya harga saham, Bank tidak dapat dimintai pertanggungjawaban. Dalam konteks pertanggungjawaban, regulasi kegiatan trust di Indonesia telah menetapkan tanggung jawab Bank sebagai Trustee dengan tegas. Hal ini sangat berbeda dengan pertanggungjawaban Trustee dalam common law yang digantungkan kepada kepercayaan penuh pada trustee dengan batasan prinsip- 
prinsip (maxim) trust. Selanjutnya, apabila terjadi kerugian investasi

yang dikelola oleh manajer investasi berlakulah asas-asas di Pasar Modal. Manajer investasi yang secara profesional dan itikad baik telah melakukan portofolio investasi, juga tidak dapat dimintai pertanggungjawaban atas kerugian yang timbul sebagai sifat investasi. Investor, dalam konteks ini adalah settlor, menanggung kerugian sebagai risiko investasi. Dalam praktik, settlor sebagai entitas bisnis tentu telah mempunyai cara untuk mengelola risiko (risk management) investasi ini sebaik mungkin. Di samping itu, PBI telah mengakomodasikan dan membebankan kewajiban pengelolaan risiko ini kepada bank yang melaksanakan kegiatan Penitipan dengan pengelolaan.

E. Gagasan Pembaruan Hukum Perdata di Indonesia terkait Penggunaan Konsep trust dalam Perjanjian Penitipan dengan Pengelolaan.

Terbitnya PBI No: 14/17/PBI/2012 tentang kegiatan Usaha Penitipan dengan pengelolaan (trust) dalam aktivitas perbankan tidak saja berkontribusi dalam pembangunan ekonomi Indonesia dengan memanfaatkan dana hasil aktivitas ekonomi khususnya Migas untuk dititipkan dan dikelola dalam bentuk investasi 
di dalam negeri, namun juga berkontribusi terhadap pengembangan dan pembangunan hukum perdata, khususnya hukum perjanjian dan hukum benda Indonesia.

Telah diuraikan sebelumnya bahwa sifat terbuka dan asas kebebasan berkontrak yang dianut oleh Buku III KUHPerdata (Pasal 1319 jo Pasal 1338 Ayat 1) membuka peluang bagi para pihak untuk membuat perjanjian baru selain yang telah ada dalam KUHPerdata dan KUHDagang. Sepanjang memenuhi syarat sah perjanjian, maka para pihak bebas menentukan bentuk, isi dan nama perjanjian sesuai kebutuhan para pihak. Namun demikian, perjanjian trust ini tidak hanya masuk dalam ranah hukum perjanjian, tetapi juga memerlukan dukungan dari aspek hukum benda, khususnya sebagai landasan hukum bagi eksistensi dual ownership. Terdapat perbedaan mendasar antara sifat buku II tentang Hukum Benda dan Buku III KUHPerdata. Hukum Benda menganut sistem tertutup, dalam arti para pihak tidak diperkenankan menciptakan kebendaan baru selain ditentukan oleh Undang-undang. Oleh karena itu, konsep trust dalam sistem common law tidak dapat diadopsi secara utuh.

Kegiatan penitipan dengan pengelolaan (trust) yang dituangkan dalam PBI merupakan pengembangan bentuk jasa penitipan yang sudah diatur dalam Pasal 6 i jo Pasal 9 UU 
Perbankan. Penamaan trust dalam PBI ini tidak semata-mata ditujukan untuk meningkatkan kepercayaan pihak ketiga, khususnya pemilik dana untuk dapat difasilitasi oleh perbankan Indonesia, namun juga sebagai langkah awal untuk mengadopsi konsep trust ini secara bertahap. Hal ini dapat dilihat dari PBI trust yang mengadopsi mekanisme Bankcruptcy remote, sebagai salah satu upaya menjamin dan melindungi kekayaan trust. Dapat disimpulkan bahwa perjanjian penitipan dengan pengelolaan (trust) berdasarkan PBI tidak sama persis dengan trust dalam sistem common law.

Melihat pada praktik penggunaan konsep trust dalam aktivitas bisnis, khususnya jasa keuangan termasuk perbankan di Indonesia, maka dapat disimpulkan bahwa perjanjian-perjanjian yang menggunakan konsep trust tidak sepenuhnya atau tidak sama dengan trust yang dikenal dalam sistem common law. Ciri konsep trust di common law system yang paling dominan adalah dikenalnya dual ownership, dimana trustee berkedudukan sebagai legal owner (pemilik secara hukum), dan pihak lainnya adalah beneficial owner (pemilik manfaat). Dalam perkembangan praktik bisnis, khususnya investasi, settlor sebagai pemilik dana (investor) menyerahkan dana kepada perusahaan Trust ( Trustee Company) untuk dikelola berdasarkan Trust, dan selanjutnya akan dinikmati manfaatnya oleh 
pemilik dana. Dalam konsep investasi melalui Trust Company, settlor adalah juga beneficiary. Hal ini pun diadopsi dalam Pasal 20 PBI Trust yang mengatur bahwa Settlor sebagai pemilik aset finansial yang dititipkan dan dikelola oleh Bank sebagai Trust dapat bertindak sebagai beneficiary.

Peneliti menyimpulkan berdasarkan data yang diolah baik data pustaka maupun hasil penelitian lapangan bahwa konsep trust yang digunakan dalam perjanjian trust di Indonesia dapat digolongkan ke dalam perjanjian yang berkembang dalam praktik. Dengan demikian, dapat dikatakan kegiatan penitipan dengan pengelolaan (trust) yang diatur dalam PBI Trust merupakan jenis perjanjian trust yang khusus digunakan dalam praktik perbankan, khususnya merupakan pengembangan jasa perbankan. Berdasarkan sistem terbuka dan asas kebebasan berkontrak dalam Buku III KUHPerdata, maka eksistensi perjanjian yang menggunakan konsep trust diakui sepanjang dibuat secara sah.

Konsep dual ownership dalam konteks hukum Indonesia tidak dapat diterapkan, namun dapat diantisipasi oleh perjanjian dan regulasi khusus. PBI tentang Kegiatan Penitipan dengan Pengelolaan (Trust) misalnya, secara tegas menyatakan bahwa Bank selaku trustee hanya dapat melakukan perbuatan hukum atas perintah tertulis. 
Namun demikian, perjanjian trust juga tidak dapat disamakan dengan perjanjian pemberian kuasa, walaupun ada unsur perintah dari settlor untuk melakukan perbuatan hukum guna kepentingan beneficiary. Jenis perjanjian bernama yang mendekati konsep perjanjian trust di Indonesia adalah Perjanjian guna kepentingan pihak ketiga (derden beding) sebagaimana diatur dalam Pasal 1317

KHUPerdata. Namun jenis perjanjian ini pun tidak sama dengan konsep trust dalam sistem common law. Pasal 1317 KUHPerdata mensyaratkan adanya persetujuan pihak ketiga untuk dapat terikat dalam perjanjian ini. Hal ini tidak disyaratkan bagi beneficiary dalam konsep trust.

Berkenaan dengan jaminan kepastian dan perlindungan hukum bagi pemilik aset finansial (settlor), maka perjanjian trust dalam konteks Indonesia harus memuat klausul-klausul yang rinci tentang kewajiban trustee, khususnya apabila trustee pailit, dilikuidasi atau tidak dapat lagi menjalankan fungsi trust. Perkembangan bisnis global yang menciptakan peluang bagi Indonesia untuk menarik sebesar-besarnya dana ke dalam negeri menjadi alasan bagi pembaruan regulasi di bidang perjanjian, khususnya untuk 
mengakomodasi secara utuh konsep trust dalam sistem hukum perjanjian.

Gagasan pengembangan perjanjian trust ini di Indonesia, selain didasarkan pada Pasal 1338 Ayat (1) yang menganut asas kebebasan berkontrak, selayaknya mengacu pada pengakuan atas prinsip hukum baru yang dikalangan bisnis diakui sebagai aturan atau kebiasaan-kebiasaan dalam praktik bisnis. Berbeda dengan trust dalam sistem common law yang lahir dari equity (kepatutan), maka perjanjian trust yang dikembangkan dalam sistem hukum Indonesia tetap berpangkal pada hukum, khususnya hukum perjanjian. Namun demikian, mengacu pada ketentuan Pasal 1339 KUHPerdata, maka perjanjian trust harus memperhatikan pula segala sesuatu yang menurut sifat perjanjian, diharuskan oleh kepatutan, kebiasaan atau undang-undang. Hal ini berarti, perjanjian trust tidak diperkenankan memperjanjikan hal-hal yang tidak patut dan dilarang oleh undangundang. Berbeda dengan trust dalam sistem common law yang lahir karena dianggap patut, guna mengisi kokosongan karena hukum tidak mengatur, maka perjanjian trust lahir berdasarkan perjanjian dengan pembatasan harus sejalan dengan kepatutan. Artinya, dalam sistem hukum Indonesia, kepatutan merupakan bagian dari hukum, sehingga 
konsep perjanjian trust tetap harus mengacu pada hukum yang berlaku. Sebaliknya, dalam sistem common law, trust lahir dari kepatutan (equity), yang terpisah dari hukum (law) dan tunduk pada prinsip-prinsip equity yang disebut dengan maxims of equity (Lastuti Abubakar, 2009 :403).

Opsi lainnya yang juga dapat ditempuh adalah adanya pranata hukum trust Indonesia yang disesuaikan dengan kebutuhan Indonesia yang bersifat komprehensif guna menangkap peluang global.

Pengaturan dual ownership dalam sistem Hukum Perdata, khususnya Hukum Benda merupakan kebutuhan mendesak bagi keberadaan perjanjian trust atau pranata trust di Indonesia. Adaptasi konsep dual ownership ke dalam sistem hukum Indonesia memerlukan dukungan pembaruan hukum, khususnya hukum perdata.

Selama ini ini pembaruan hukum Perdata Indonesia dilakukan secara parsial, berdasarkan kebutuhan yang mendesak. Oleh karena itu pilihan untuk melakukan pembaruan KUHPerdata bukan opsi terbaik, mengingat sulitnya membuat kodifikasi hukum Perdata secara utuh. Sistem pembaruan Hukum perdata Indonesia dapat dilakukan dengan membuat aturan-aturan dalam bentuk 
Undang-undang yang secara khusus mengatur materi muatan tertentu. Oleh karena itu, KUHPerdata tidak lagi berlaku utuh seperti saat diundangkan. Berdasarkan metode pembaruan hukum Perdata di atas, maka konsep trust dapat dimasukkan dalam ketentuan khusus yang mengatur tentang Trust sebagai bagian dari Hukum Perdata Indonesia. Diharapkan ketentuan khusus ini dapat menjadi payung hukum bagi aktivitas yang menggunakan konsep trust di Indonesia.

\section{SIMPULAN DAN SARAN}

A. Simpulan

1. Perjanjian penitipan dengan pengelolaan (trust) yang diatur dalam PBI No: 14/17/PBI/2012 ini merupakan pengembangan dari kegiatan penitipan berdasarkan kontrak yang sudah diatur dalam Pasal 6 I jo Pasal 9 UU Perbankan. Berdasarkan sistem terbuka dan asas kebebasan berkontrak yang dianut Buku III KUHPerdata, perjanjian ini merupakan salah satu jenis perjanjian 
tidak bernama yang timbul dalam praktik perbankan guna memanfaatkan peluang untuk meningkatkan devisa Negara dari sektor industri Migas. Namun demikian, perjanjian penitipan dengan pengelolaan ini hanya mengadopsi sebagian dari konsep trust yang dikenal dalam sistem common law, yakni penggunaan bankcruptcy remote, dimana kekayaan trust dipisahkan dari kekayaan bank. Konsep dual ownership dan peralihan kekayaan trust dari settlor dalam trust tidak dikenal dalam sistem hukum perdata di Indonesia. Oleh karena itu, PBI mengatur secara tegas bahwa kekayaan trust tidak beralih kepada Bank sebagai trustee, dan kewenangan trustee untuk mengelola kekayaan trust harus berdasarkan perintah tertulis dan sesuai dengan perjanjian trust yang telah disepakati.

2. Bank Tidak bertanggung jawab atas kerugian investasi yang timbul akibat pengelolaan kekayaan trust yang menjadi objek perjanjian penitipan dengan pengelolaan sepanjang Bank telah melakukan instruksi sesuai perjanjian. Bank harus bertanggung jawab apabila kerugian timbul karena kelalaian Bank baik berupa kelalaian mematuhi kewajiban yang timbul dari peraturan perundang-undangan maupun dari perjanjian trust. Dengan 
demikian, Bank dapat dimintai pertanggungjawaban atas kerugian baik berdasarkan perbuatan melawan hukum maupun wanprestasi berdasarkan sistem hukum perjanjian Indonesia.

3. Terbitnya PBI No : 14/17/PBI/2012 tentang Kegiatan penitipan dengan pengelolaan, telah mengubah peta hukum perjanjian Indonesia, khususnya perjanjian tidak bernama yang berkembang dalam praktik perbankan. Mengingat konsep trust mengenal dual ownership yang tidak dikenal dalam sistem hukum benda Indonesia, maka diperlukan pembaruan hukum perdata, khususnya hukum benda untuk mengakomodasikan dualownership dalam hukum perdata Indonesia. Pembaruan hukum perdata yang dianggap tepat adalah dengan menerbitkan peraturan khusus yang mengatur tentang trust sebagai paying hukum bagi kegiatan yang menggunakan konsep trust.

B. Saran

Berdasarkan kesimpulan yang telah diambil,maka tim peneliti menyarankan hal-hal sebagai berikut :

1. Diperlukan pengawasan oleh otoritas perbankan, dalam hal ini Bank Indonesia untuk memantau perjanjian baku yang digunakan oleh perbankan terkait perjanjian penitipan dengan pengelolaan 
ini guna menjamin kepastian dan perlindungan hukum bagi pemilik dana (settlor)

2. Diperlukan landasan hukum yang kokoh untuk memfasilitasi kegiatan yang menggunakan konsep trust di Indonesia. Pilihan infrastruktur legal yang dianggap tepat untuk menjadi payung hukum adalah UU Tentang Trust.

3. Diperlukan upaya untuk mendorong perbankan nasional memenuhi persyaratan sebagai trustee.

\section{DAFTAR PUSTAKA}

Bank Indonesia, Kajian Mengenai Dampak Kebijakan BP Migas-Potensi Sumber Devisa: Fakta, Peluang dan Tantangan Kebijakan, DKMDhk,DPNP,DSM,Dint,DPD,DPB 1, Tanpa Tahun. 
Sydenham, Angela. 2000, Nutshells : Equity \& Trusts, Sweet \& Maxwell, London.

Gilissen, John. \& Frits Gorle, 2005, Sejarah Hukum : Suatu Pengantar (terjemahan oleh Freddy Tengker), Jakarta.

Lastuti, Abubakar, 2009, Transaksi Derivatif di Indonesia (Tinjauan Hukum Tentang Perdagangan Derivatif di Bursa Efek, Terrace Book Library, Bandung.

Sumadi, 1988, Metode Penelitian, CV Rajawali, Jakarta.

Soerjono, Soekanto, 1982, Penelitian Hukum, UI Press, Jakarta.

Mack. William \& Donald J. Keser, 1938, Corpus Juris Secundum, Bank and Banking, Volume IX, The American Law Book Co.

\section{PERATURAN PERUNDANG-UNDANGAN}

Kitab Undang-Undang Hukum Perdata.

Undang-Undang No. 7 Tahun 1992 sebagaimana diubah dengan UU No. 10 Tahun 1998 Tentang Perbankan.

Undang-undang No : 8 Tahun 1995 Tentang Pasar Modal.

Undang-Undang No. 23 Tahun 1999 sebagimana diubah dengan UU No :

3 Tahun 2004 Tentang Bank Indonesia.

Peraturan Bank Indonesia No 14/17/PBI/2012 tentang Kegiatan usaha Bank Penitipan dan Pengelolaan (trust). 


\section{JURNAL, MAKALAH DAN ARTIKEL}

Loghlin, Peter Joseph., The Domestication of The Trust : Bridging The Gap Between Common Law and Civil Law, http://jurisconsultsgroup.com/trusts.htm.

Tri Handayani, dkk., 2013, Upaya Perlindungan Terhadap Pihak Ketiga Dalam Perjanjian Trust sebagai Perjanjian Dalam Perkembangan, Penelitian.

\section{LAIN-LAIN}

Hasil wawancara dengan Asisten Direktur Departemen kebijakan Makroprudensial, Bank Indonesia, Bapak Indra Gunawan dan Manajer Depertemen Kebijakan, Bank Indonesia, pada Selasa tanggal 26 November 2013 pkl 15.00 - selesai.

Surat Kebijakan BP Migas No.kep-0066/BP00000/2008/SO Tahun 2008 Visi Arsitektur Perbankan Indonesia PI dalam Arsitektur Perbankan Indonesia (API). 